\title{
Iris x hollandica (Iridaceae): a valid name for Dutch Iris
}

\author{
Julian M. H. Shaw \\ Royal Horticultural Society, Wisley, Woking, UK
}

\section{Corresponding author: julianshaw@rhs.org.uk}

This pdf constitutes the Version of Record published on $26^{\text {th }}$ July 2021

\begin{abstract}
The history and origin of the race of Iris known as 'Dutch Iris' and the validity of the name Iris $\mathrm{x}$ hollandica are investigated. It is concluded that the name was validly published as Iris $\times$ hollandica H.R.Wehrh., Gartenstaud. 2: 231. 1931. Subsequently this name has been listed in IPNI.
\end{abstract}

\section{Introduction}

This is one of a series of papers investigating the history and validity of so called 'hort.' names of unknown authorship that have been applied to garden plants in horticultural literature but never investigated for authorship or validity under the terms of the International Code of Botanical Nomenclature. Such names are often employed in Floras and lists of established 'alien' plants when no other name is available. As in this case, it often transpires that they have been validly published, sometimes unintentionally.

Dutch Iris (Fig. 1) is a well-known and widely grown race of garden plants derived from species of Iris section Xiphium, however uncertainty has persisted over their valid botanical name. The history of naming this group is investigated below.

\section{Origins}

Dutch Iris is a race of hybrids that was developed independantly in Holland during the early 1900's by two different bulb companies at the same time: Van Tubergen in Haarlem and Jan de Graaff in Leiden, which later became De Graaff Brothers. During the summer of 1909, Joseph Jacob, an enthusiastic English bulb grower who was Vicar of Whitewell from 1884-1926 had suggested to the Hoog family at Zwanenburg, who were then running the Van Tubergen nurseries, that their new race of Iris be called 'Dutch Iris', a name that met with immediate acceptance and has been used ever since. Jacobs seemed very proud of this naming and displayed a constant interest in the development of these hybrids for the rest of his life, referring to himself as the 'godfather of the old Dutch Irises' (Jacobs, 1920). In their catalogues from 1910 until 1983 van Tubergen used the term Dutch irises without further qualification.

Meanwhile, the catalogues issued by De Graaff also used the name Dutch Iris until around 1920. However, in 1922 the Scandinavian catalogue of S.A. Konijneburg \& Co, Noordwijk, which later became De Graaff \& Konijneburg, and subsequently traded as Grakon, introduced the term Iris Hollandia (Dutch iris) to distinguish Dutch Iris from Iris hispanica. Later in 1925 de Graaff Brothers, Noordwijk in the English 
edition of their wholesale catalogue, reverted to the term 'Dutch Iris' describing them as 'a new race of early Xiphiums ... in advance of Iris Hispanica'. Subsequently from 1947-1973 their catalogues use Iris Hollandia, which then changed in 1974 to Iris hollandica.

In 1983 new management took over at Van Tubergen and also commenced using the name Iris hollandica in addition to Dutch Iris in their catalogues.

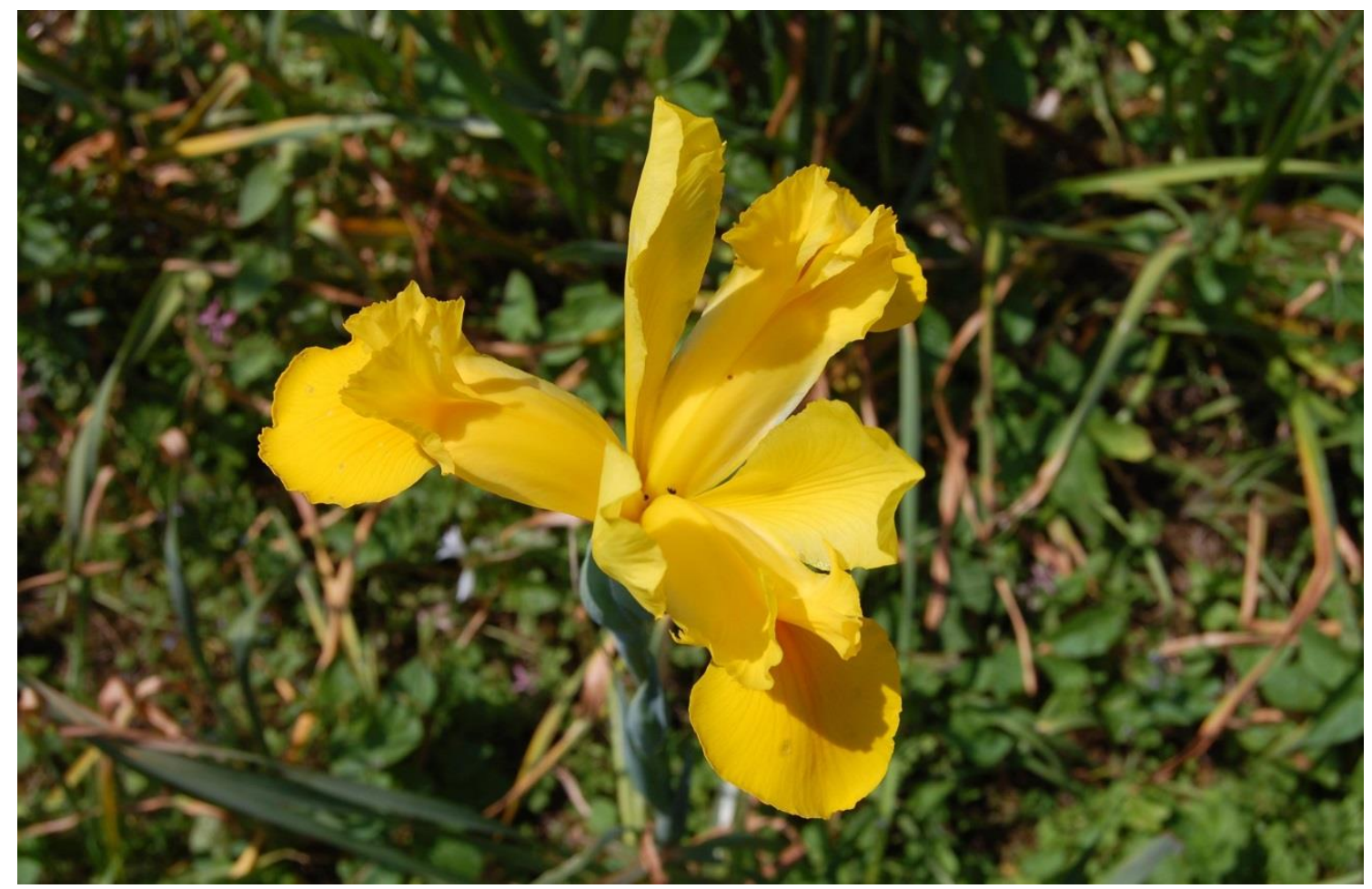

Figure 1. Dutch Iris 'Yellow Gold' on St Martins, Scilly, 2008. Photo: Colin Wild

Van Tubergen staff, notably John Hoog, (Johannes Marius Cornelis Hoog, 1865-1950) and Cornelis Gerrit van Tubergen (1844-1919) were very active in promoting botanical exploration and subsequent importation and introduction to European cultivation of new bulbs (Hoog, 2013, Hoog, 2015). Many of these they named and described, providing now familiar valid names, including Scilla tubergeniana Hoog \& Stearn, Tulipa fosteriana Hoog ex B.Fedtsch. Tulipa praestans Tubergen ex Hoog - and even an artificial intergeneric hybrid between Amaryllis belladonna and Brunsvigia as $\times$ Brunsdonna Tubergen ex Worsley. In contrast, the name for their garden hybrid Iris $\mathrm{x}$ hollandica was never formally published as a botanical binomial by staff of either bulb company. As a result the KAVB [Royal General Bulbgrowers' Association] which is the International cultivar registration authority (ICRA) for bulbous irises in their Checklists provided the entry "hollandica see Dutch Iris Group".

Evidently feeling the need for a botanical name, Iris $\mathrm{x}$ hollandica was taken up by authors of several works. The European Garden Flora (Matthews, 1986) mentions it in passing attributing it to Anon., and a few other horticultural works cite it as $I$. $\mathrm{x}$ hollandica Hoog, or I. x hollandica Tubergen. Graff's Exotica (1978) is quite inconsistent and within two pages uses, "Iris xiphium var hollandica", "Iris xiphium hybrids (Dutch Iris)" and " Iris 'Wedgwood"'. Brian Mathew's The Iris (1981), does 
mention Dutch Iris but did not mention these other names that were in horticultural use.

However, David McClintock, in his The wild flowers of Guernsey (1975) introduces the name to botanical literature when he recorded Dutch Iris as established in the Channel Isles, later revealing its source as a garden throw-out (McClintock, 1987). More recently it has been recorded as a relic of cultivation from the Isles of Scilly, along with Iris xiphium, a putative parent (Parslow \& Bennallick, 2017). McClintock seems to be responsible for this name gaining a foot-hold in botanical works, as his record was passed from one reference work to another in publications by members of the Botanical Society of the British Isles (BSBI), such as the comprehensive work by Clement and Foster (1994) Alien plants of the British Isles, and Clive Stace's influential New Flora (Stace, 1991, 2019), and the critical Flora (Sell \& Murrell, 1996). The fact that it was a naturalised hybrid, ensured a treatment in Stace's Hybrid Flora where however it is treated as "Iris x hollandica hort., nom. nud." (Stace et al., 2015). By this time plants of Dutch Iris had become an established introduction elsewhere and consequently the name, Iris $\mathrm{x}$ hollandica is included as a valid binomial, keyed out with description in a taxonomic paper on Iris in Kashmir (Akhter et al., 2012), but attributed to Hort. without a publication reference. Searches on academic internet engines and libraries such as JSTOR and Google Scholar revealed widespread use of $I$. x hollandica as a botanical name in papers on phytochemistry, virology, horticulture and more recently floristics.

\section{Valid publication}

Up until $1^{\text {st }}$ January 1958 citation of a type specimen was not a requirement for valid publication of a species (Turland, 2013), hence a search of horticultural publications that provided reasonable descriptions and statements of parentage prior to 1958 eventually revealed a presumably unintentional validation of the name Iris $\mathbf{x}$ hollandica. Such a publication was provided in a German gardening encyclopaedia Die Gartenstauden by Wehrhahn (1931). He gives the name as ' $I$. hollandica hort. Tub.' along with the parentage, and a description. This reference was subsequently accepted by the editors of IPNI for inclusion as Iris $\times$ hollandica H.R.Wehrh. Gartenstaud. 2: 231. 1931. As discussed above Van Tubergen evidently did not originate or use this name in early catalogues; it appears to have been originated by De Graaff, first as I. hollandia and later as I. hollandica which later spelling is now accepted, hence the author citation originally used by Wehrhahn has not been adopted.

\section{Parentage}

Another question that remains open to further investigation is the parentage of Iris $\mathbf{x}$ hollandica. Stace $(1991,2019)$ gives it as Iris filifolia x I. tingitana, whereas Clement and Foster (1994) and Sell \& Murrel (1996) regard it as 'a complex of hybrids involving I. filifolia, I. latifolia, I. tingitana and I. xiphium.' In the Hybrid Flora (Stace et al., 2015) this is modified to I. filifolia x I. tingitana, with possibly I. xiphium, where as Mathew (1981) suggests I. xiphium and I. tingitana, possibly with $I$. latifolia influence. Flora Iberica (Crespo, 2013) raised subgenus Xiphium to generic rank, and adopted the name Xiphium vulgare in place of Iris xiphium, listing the parents of Dutch Iris as $X$. vulgare with $X$. filifolium and $X$. tingitanum, which agrees with the parentage suggested by Stace et al., (2015). The noted Iris enthusiast, 
William Dykes was curious about the parentage of this then new race of Iris, and commented in his Handbook, 'When these first appeared they were said to be hybrids of various species of the Xiphium section, though there was no internal evidence of this. Subsequently, however, some blue-purple varieties appeared, which clearly showed the influence of $I$. tingitana, both in the shape of the falls and in the presence of a tube between the ovary and the base of the segments.' He attributes further confusion over parentage to the use of an early flowering form of what is now I. xiphium 'Praecox' under the name of I. filifolia (Dykes, 1924).

\section{Acknowledgments}

Without a stream of queries originating from David Mabberley on the validity of botanical names used in horticultural works but omitted from IPNI, as he prepared the 4th edition of Mabberley's Plant Book, this name, Iris x hollandica, might still be in nomenclatural limbo. Jennifer Hewitt, Cultivar Registrar for Iris, British Iris Society, kindly provided information on cultivars. It is to Johan van Scheepen, now retired, former Taxonomist and Librarian, Koninklijke algemeene Vereeniging voor bloembollculture [Royal General Bulbgrowers' Association] (KAVB) Hillegom, The Netherlands, that I am most indebted. He trawled through many rare nursery catalogues to discover the original and early uses of the name. Further helpful assistance was provided by the staff of the Lindley Library, Royal Horticultural Society.

\section{References}

Akhter, C., Khuroo, A.A., Malik, A.H. \& Dar, G.H. 2012. A taxonomic appraisal of genus Iris L. in Kashmir, Himalaya, India. Iranian J. Bot. 19(2): 119-126.

Clement, E.J. \& Foster, M.C. 1994. Alien plants of the British Isles. London: Botanical Society of the British Isles.

Crespo, M.B. 2013. Xiphion. In Rico, E., Crespo, M.B., Quintanar, A., Herrero, A. \& Aedo, C., eds. Flora Iberica 20: 431-441. Madrid: Real Jardín Botánico, CSIC.

Dykes, W.R. 1924. Handbook of garden irises. London: Martin Hopkinson \& Co. pp. 65-66, 72.

Graff, A.B. 1978. Exotica Ser. 3, ed. 9., p. 1005. Rutherford, New Jersey: Roehrs Company.

Hoog, C. 2015. John Hoog, pioneering bulb dealer. The Plantsman, new series. 14(3): 178-181.

Hoog, K. 2013. De Bollen Zijn Weer Best [The bulbs are good again]. Uitgeverij Verloren.

Jacob, J. 1920. Dutch and Spanish Irises. The Garden: 538-539 (30 Oct 1920).

McClintock, D. 1975. The wild flowers of Guernsey. London: Collins. p.234.

McClintock, D. 1987. Supplement to The wild flowers of Guernsey. La Societe Guernesiaise, St. Peter Port. p.42.

Mathew, B. 1981. The Iris. London: Batsford.

Matthews, V. 1986. Iris. In Walters, S.M. et al., eds. The European Garden Flora 1: 351. Cambridge: Cambridge University Press.

Parslow, R.E. \& Bennallick, I.J. 2017. The new Flora of the Isles of Scilly. Cornwall: Parslow Press.

Sell, P. \& Murrell, G. 1996. Flora of Great Britain and Ireland. Vol. 5. Cambridge: Cambridge University Press. 
Stace, C. 1991. New Flora of the British Isles. Cambridge: Cambridge University Press.

Stace, C. 2019. New Flora of the British Isles. $4^{\text {th }}$ ed. Middlewood Green, Suffolk: C \& M Floristics.

Stace, C., Preston, C.D. \& Pearman, D.A. 2015, Hybrid flora of the British Isles. Bristol: Botanical Society of Britain and Ireland. p.359

Turland, N. 2013. The Code decoded. Regnum Vegetabile 155. Konigstein: IAPT/Koeltz Scientific books. p.117.

Wehrhahn, H.R. 1931. Die Gartenstauden (Band I), p. 231. Berlin: Paul Parey.

Copyright retained by author(s). Published by BSBI under the terms of the Creative Commons Attribution 4.0 International Public License.

ISSN: $2632-4970$

https://doi.org/10.33928/bib.2021.03.227 